\title{
MOTIVASI BERWIRAUSAHA, MANAJEMEN WAKTU, MANAJEMEN KEUANGAN, DAN PRESTASI AKADEMIK PADA MAHASISWA WIRAUSAHA
}

\author{
Ulfi U'rfillah ${ }^{1 *}$, Istiqlaliyah Muflikhati ${ }^{1}$ \\ 1 Departemen IImu Keluarga dan Konsumen, Fakultas Ekologi Manusia, Institut Pertanian Bogor, \\ Bogor 16680, Indonesia \\ *)E-mail: adinka130411@gmail.com
}

\begin{abstract}
Abstrak
Penelitian ini bertujuan untuk menganalisis pengaruh karakteristik mahasiswa, karakteristik keluarga, karakteristik usaha, motivasi berwirausaha, manajemen waktu, dan manajemen keuangan terhadap pertumbuhan usaha dan prestasi akademik mahasiswa wirausaha. Penelitian ini melibatkan 50 orang mahasiswa yang telah menjalankan usaha (pertanian atau nonpertanian) minimal selama tiga bulan. Contoh dipilih dengan teknik snowball dengan informan kunci pertama adalah ketua komunitas wirausaha di perguruan tinggi terpilih. Data dikumpulkan melalui wawancara dan dianalisis dengan menggunakan analisis deskriptif, uji beda $t$-test, analisis faktor, dan uji regresi linear berganda. Penelitian menunjukkan bahwa motivasi berwirausaha mahasiswa berada pada kategori tinggi. Faktor yang paling memotivasi mahasiswa dalam berwirausaha adalah faktor capaian bisnis yang besar. Manajemen keuangan dan manajemen waktu mahasiswa wirausaha berada pada kategori sedang. Persentase terbesar pertumbuhan usaha mahasiswa berada di interval 0,0-20,0 persen per bulan. Mahasiswa wirausaha yang berjenis kelamin perempuan mempunyai prestasi akademik yang lebih baik. Penelitian ini menemukan bahwa pertumbuhan usaha mahasiswa wirausaha dipengaruhi secara positif signifikan oleh pendidikan dan pekerjaan ayah. Prestasi akademik mahasiswa wirausaha dipengaruhi secara negatif signifikan oleh keikutsertaan Program Kreatifitas Mahasiswa bidang Kewirausahaan dan pertumbuhan usaha, namun dipengaruhi secara positif signifikan oleh jalur masuk dan manajemen keuangan.
\end{abstract}

Kata kunci: mahasiswa wirausaha, manajemen keuangan, manajemen waktu, motivasi berwirausaha, prestasi akademik

\section{Entrepreneurial Motivation, Time Management, Financial Management, and Academic Ahievement of College Entrepreneurs}

\begin{abstract}
This study aimed to analyze the influence of sample characteristics, family characteristics, business characteristics, entrepreneurial motivation, time management, and financial management toward business growth and academic achievement of college entrepreneurs. The study involved 50 college students (32 male and 18 female) who have been in business (agriculture or non-agricultural) for at least three months. Samples chosen by snowball technique with the first key informant is the head of the entrepreneurial community. Data were collected through interviews and analyzed using independent sample t-test, factor analysis, and multiple linear regression. Research showed that category of entrepreneurial motivation was high. The most motivating factor for college entrepreneurs was a greater business achievement. Category of financial and time management of college entrepreneurs were in the medium. The largest percentage of business growth was between 0,0 to 20,0 percent per month. Female entrepreneurs have better academic achievement than male entrepreneurs. The study found that the business growth is significantly positively influenced by the education and occupation of the father. The academic achievement of college entrepreneurs is negatively influenced by the participation of the Entrepreneurship Student Creativity Program and business growth, but it is positively influenced significantly by college entrance pathways and financial management.
\end{abstract}

Keyword: college entrepreneur, financial management, time management, entrepreneurial motivation, academic achievement

\section{PENDAHULUAN}

Hasil proyeksi penduduk pada Juli 2015 menunjukkan bahwa jumlah penduduk Indonesia sebanyak 255.461 .700 orang. Jumlah ini meningkat dibandingkan dengan jumlah penduduk Indonesia pada Juli 2014 yang berjumlah 252.164.000 orang (BPS, 2015a). Peningkatan penduduk ini berdampak pada bertambahnya jumlah pengangguran. Tingkat Pengangguran Terbuka (TPT) mengalami peningkatan dari 5,94 persen di bulan 
Agustus 2014 menjadi 6,18 persen pada Agustus 2015.

Faktor utama penyebab pengangguran adalah besarnya angkatan kerja tidak seimbang dengan kesempatan kerja (Muhdar, 2015). Ketidakseimbangan terjadi apabila jumlah angkatan kerja lebih besar daripada kesempatan kerja yang tersedia. Pengangguran bisa juga disebabkan oleh keterbatasan kemampuan, keterbatasan informasi, ketidakmerataan lapangan kerja, dan rendahnya upaya pemerintah untuk meningkatkan keterampilan (skill) tenaga kerja. Pengangguran berdampak besar pada bidang ekonomi, seperti munculnya masalah kemiskinan, terhambatnya perkembangan ekonomi, dan juga dapat merambat pada bidang lain seperti: politik, sosial, moral, dan mental.

Pengangguran yang meningkat akan meninggalkan masalah sosial yang kompleks. Oleh karenanya, bukan hanya tugas negara saja yang harus berusaha keras untuk menekan pengangguran. Sukidjo (2005) mengatakan bahwa dalam mengatasi pengangguran dapat dilakukan secara langsung maupun tidak langsung. Secara langsung, pemerintah dapat langsung membuka lapangan kerja sedangkan secara tidak langsung pemerintah dapat menciptakan program yang dapat meningkatkan pengetahuan, keterampilan, serta menumbuhkan sikap kewirausahaan melalui pengembangan kewirausahaan. Pengembangan kewirausahaan telah dilakukan oleh berbagai pihak. Salah satu lembaga yang telah menjalankan program yang bertujuan untuk mengembangkan kewirausahaan khususnya pada generasi muda adalah Direktorat Jendral Pendidikan Tinggi (DIKTI) melalui Program Kreativitas Mahasiswa bidang Kewirausahaan (PKM-K). Selain itu, berbagai perguruan tinggi di Indonesia juga mengembangkan kebijakan di universitas masing-masing yang bertujuan untuk menumbuhkembangkan jiwa, minat, dan kemampuan wirausaha mahasiswa.

Badan Pusat Statistika (2015b) mengungkapkan sebanyak 57,8 persen dari total angkatan kerja bekerja pada sektor informal. Namun hanya 19,2 persen yang berusaha sendiri atau berwirausaha. Angka wirausaha tersebut mengalami penurunan dari tahun sebelumnya yang mencapai 20,5 persen. Salah satu penyebab rendahnya angka wirausaha di Indonesia adalah tata kelola atau manajemen yang kurang baik. Manajemen adalah sebuah proses dalam penggunaan sumber daya untuk mencapai tujuan atau untuk mendapatkan sesuatu yang diinginkan. Proses tersebut dimulai dari identifikasi, mengimplementasikan, hingga evaluasi. Oleh karenanya, menumbuhkembangkan jiwa, minat, dan kemampuan berwirausaha pada mahasiswa juga harus disertai dengan edukasi tentang menajemen sumber daya yang dimiliki mahasiswa; mengingat status sebagai pelajar yang sedang menuntut ilmu tidak dapat terpisahkan. Waktu, tenaga, dan uang merupakan sumber daya yang penting di dalam manajemen. Begitu pula bagi mahasiswa yang sedang merintis usaha saat kuliah. Pengelolaan waktu, tenaga, dan uang tentu saja menjadi penting karena selain membuat usahanya berhasil mahasiswa juga masih harus menyelesaikan studinya dengan hasil yang baik.

Waktu adalah sumber daya utama yang dimiliki oleh setiap manusia dalam bekerja. Bagi negara berkembang peranan sumber daya lainnya, seperti modal (uang) dalam proses memperoleh barang dan jasa sangat kecil karena pada umumnya hanya dimiliki dalam jumlah yang kecil. Manajemen waktu adalah tindakan untuk memperoleh sebuah penggunaan waktu yang efektif ketika melakukan tindakan tertentu yang megarah pada tujuan (Claessens et al., 2007; Goldsmith, 2010). Dalam konteks berwirausaha, manajemen waktu menjadi hal penting yang dilakukan agar usaha berjalan sesuai dengan tujuan.

Selain manajemen waktu, kemampuan dalam mengelola keuangan atau biasa dikenal sebagai manajemen keuangan juga diperlukan dalam menjalankan sebuah usaha. Manajemen keuangan adalah ilmu atau praktek mengelola uang atau aset lainnya. Manajemen keuangan juga dapat diartikan sebagai kemampuan untuk menetapkan tujuan dan kemampuan untuk menempatkan kebutuhan masa depan sebelum kebutuhan saat ini (Goldsmith, 2010). Oleh karena itu, manajemen waktu dan manajemen keuangan penting dikuasai mahasiswa agar suksesmenggapai tujuan dalam berwirausaha sekaligus sukses dalam studinya.

Kepemilikan motivasi untuk berwirausaha secara psikologis juga dapat menyebabkan seseorang berwirausaha (Amalia, 2011). Motivasi yang baik dalam berwirausaha akan meningkatkan kemungkinan kesuksesan dalam usaha yang dapat dilihat dari pertumbuhan usahanya (Toledo et al., 2012). Motivasi dalam manajemen mengacu pada gerakan mencapai tujuan atau hasil yang diinginkan serta untuk 
memiliki semangat, dorongan, ketekunan, kreativitas, arahan, dan energi berkelanjutan (Goldsmith, 2010). Stefanovic, Prokic, dan Rankovic (2010) mengemukakan terdapat empat faktor motivasi yang menjadi faktor penting dalam mendirikan usaha, yaitu capaian bisnis yang besar (great business achievement), kebebasan (independent), faktor intrinsik (intrinsic factor), dan keamanan kerja (job security). Penelitian yang sama dilakukan oleh Benzing, Chu, dan Kara (2009) yang menemukan bahwa terdapat empat faktor penting yang memotivasi seseorang dalam mendirikan usaha, yaitu faktor keamanan (security factor), faktor pendapatan (income factor), faktor kebebasan (independent factor), dan faktor intrinsik (intrinsic factor). Sementara itu, Chu, Benzing, dan Mcgee (2007) mengemukakan bahwa ada tiga faktor penting dalam mendirikan usaha, yaitu kesuksesan karir objektif, kesuksesan karir subjektif, dan efek warisan.

Salah satu elemen dari kesuksesan berwirausaha adalah pertumbuhan usaha (Perren, 1999). Pertumbuhan usaha dapat dilihat dari pertumbuhan jumlah produksi, penjualan, pendapatan, dan laba. Hal tersebut menjadi tantangan tersendiri ketika yang berwirausaha adalah seorang mahasiswa. Seorang mahasiswa yang berwirausaha memiliki tujuan lain yaitu juga memiliki capaian prestasi akademik yang tinggi. Mahasiswa yang berwirausaha harus mengembangkan kemampuannya untuk memeroleh keterampilan yang dibutuhkan dalam mencapai kedua tujuan tersebut.

Berwirausaha berarti bersedia mengambil resiko pribadi (Riyanti, 2003). Begitu juga dengan mahasiswa wirausaha yang memiliki peran ganda. Selain harus fokus terhadap usaha yang dikembangkannya, mahasiswa wirausaha juga dituntut untuk menjalankan kewajibannya sebagai mahasiswa, yaitu belajar dan menyelesaikan kuliahnya. Pambudy et al. (2011) mengatakan bahwa sebagian besar mahasiswa telah memiliki pengalaman dalam berwirausaha. Hanya saja mahasiswa IPB yang berhasil dalam berwirausaha memiliki Indeks Prestasi Kumulatif (IPK) senilai 2,00-2,50. Oleh karenanya, perlu ada kajian lebih lanjut untuk dapat menganalisis motivasi dan juga manajemen waktu dan keuangan yang dilakukan oleh mahasiswa wirausaha sebagai prediktor kesuksesan wirausaha sekaligus kesuksesan akademiknya.

Penelitian ini bertujuan untuk menganalisis karakteristik (individu, keluarga, dan usaha), motivasi berwirausaha, manajemen waktu, manajemen keuangan, pertumbuhan usaha, dan prestasi akademik mahasiswa yang berstatus wirausahawan/wati. Penelitian ini bertujuan juga untuk menganalisis pengaruh karakteristik (individu, keluarga, dan usaha), motivasi berwirausaha, manajemen waktu, dan manajemen keuangan terhadap pertumbuhan usaha mahasiswa wirausaha. Selain itu, penelitian ini juga bertujuan untuk menganalisis pengaruh karakteristik (individu, keluarga, dan usaha), manajemen waktu, manajemen keuangan, dan pertumbuhan usaha terhadap prestasi akademik mahasiswa wirausaha.

\section{METODE}

Desain yang digunakan dalam penelitian ini adalah exploratory. Penelitian ini dilaksanakan di salah satu perguruan tinggi di Bogor. Perguruan tinggi tersebut dipilih sebagai lokasi penelitian karena merupakan perguruan tinggi yang menjadikan kewirausahaan sebagai salah satu visi institusi. Pengambilan data dilakukan pada bulan Maret sampai dengan bulan April tahun 2016.

Penelitian ini melibatkan 50 orang mahasiswa aktif yang telah menjalankan usaha (pertanian atau nonpertanian) minimal selama tiga bulan sebagai contoh penelitian. Contoh dipilih dengan teknik snowball dengan key-pearson pertama adalah Ketua Komunitas Wirausaha di perguruan tinggi terpilih (Enterpreneurs Community). Komunitas ini berkontribusi dalam pengembangan kewirausahaan sekaligus sebagai badan/ wadah yang melakukan pembinaan terpadu terhadap mahasiswa wirausaha di perguruan tinggi terpilih. Komunitas ini memiliki visi untuk membumikan kewirausahaan di perguruan tinggi terpilih.

Jenis data yang digunakan dalam penelitian ini adalah data primer. Data primer diperoleh melalui wawancara dengan menggunakan kuesioner. Data primer yang dikumpulkan meliputi karakteristik individu (usia, jenis kelamin, uang saku, sumber uang saku, beasiswa, mayor, semester, minor, suku asal, jalur masuk, keikutsertaan organisasi, keikutsertaan pelatihan kewirausahaan, keikutsertaan kuliah kewirausahaan, dan keikutsertaan program kreativitas mahasiswa), karakteristik keluarga (lama pendidikan orang tua, pekerjaan orang tua, pendapatan keluarga, dan jumlah tanggungan), karakteristik usaha (jenis usaha, bidang usaha, lama usaha, modal awal, penjualan awal, penjualan usaha, dan laba usaha), motivasi berwirausaha, dan manajemen keuangan,manajemen waktu, 
pertumbuhan usaha, dan prestasi akademik mahasiswa.

\begin{abstract}
Motivasi berwirausaha adalah dorongan yang membantu menguatkan perilaku berwirausaha. Instrumen yang digunakan untuk mengukur motivasi merupakan modifikasi dari instrumen Stefanovic, Prokic, dan Rankovic (2010). Instrumen yang digunakan terdiri atas 10 butir pertanyaan dengan pilihan jawaban menggunakan skala Likert yang terdiri dari 5 pilihan mulai dari tidak sesuai dengan diri saya (nilai 1) sampai dengan sangat sesuai dengan diri saya (nilai 5). Instrumen yang digunakan telah reliabel dengan nilai Cronbach'sa alpha sebesar 0,650. Dalam proses pengolahan datanya, skor yang diperoleh dari instrumen selanjutnya dijumlahkan dan diolah menjadi indeks. Selanjutnya berdasarkan indeks, motivasi berwirausaha pada mahasiswa wirausaha dikategorikan menjadi tiga kategori yaitu rendah $(0,0-50,0)$, sedang $(50,0-75,0)$, dan tinggi $(75,0-100,0)$.
\end{abstract}

Manajemen waktu mahasiswa wirausaha adalah pengelolaan waktu yang dilakukan oleh mahasiswa wirausaha. Instrumen untuk mengukur manajemen keuangan mahasiswa wirausaha adalah modifikasi dari instrumen Puspitawati (2004). Instrumen yang digunakan dalam penelitian ini telah reliabel dengan nilai Cronbach's alpha sebesar 0,781. Instrumen ini terdiri atas 7 butir pernyataan dengan pilihan jawaban menggunakan skala Likert dengan 5 pilihan jawaban; mulai dari tidak pernah (skala 1) sampai dengan selalu (skala 5). Skor yang diperoleh dari instrumen hasil wawancara dengan responden, selanjutnya dijumlahkan dan diolah menjadi indeks. Selanjutnya berdasarkan indeks, manajemen waktu mahasiswa wirausaha dikategorikan menjadi tiga kategori yaitu rendah $(0,0-50,0)$, sedang $(50,0-75,0)$, dan tinggi $(75,0-100,0)$.

Manajemen keuangan mahasiswa wirausaha adalah pengelolaan keuangan yang dilakukan oleh mahasiswa wirausaha. Instrumen untuk mengukur manajemen keuangan mahasiswa wirausaha adalah modifikasi dari instrumen Puspitawati (2004). Instrumen ini telah reliabel dengan nilai Cronbach's alpha sebesar 0,777. Instrumen ini terdiri atas 11 butir pernyataan dengan pilihan jawaban menggunakan skala Likert yang terdiri dari 5 pilihan skala jawaban; mulai dari tidak pernah (skala 1) sampai dengan selalu (skala 5). Skor yang diperoleh dari instrumen, selanjutnya dijumlahkan dan diolah menjadi indeks. Selanjutnya berdasarkan indeks, manajemen keuangan mahasiswa wirausaha dikategorikan menjadi tiga kategori yaitu rendah $(0,0-50,0)$, sedang $(50,0-75,0)$, dan tinggi $(75,0-100,0)$.

Sementara itu, pertumbuhan usaha dapat dilihat dari pertumbuhan jumlah produksi, penjualan, pendapatan, dan laba. Dalam penelitian ini, pertumbuhan usaha dilihat dari pertumbuhan penjualan. Pertumbuhan penjualan dikelompokkan menjadi tiga kategori yaitu kurang dari 0,0 persen per bulan, 0,0-20,0 persen per bulan, dan lebih dari 20,0 persen per bulan.

Variabel terikat lain pada penelitian ini adalah prestasi akademik mahasiswa wirausaha yang merujuk pada capaian mahasiswa pada bidang akademik yang diukur berdasarkan Indeks Prestasi Kumulatif (IPK). IPK mahasiswa dikelompokkan menjadi 4 kategori yaitu kurang dari 2,$50 ; 2,50-3,00 ; 3,01-3,50$; dan 3,51-4,00.

Analisis data yang digunakan dalam penelitian ini adalah analisis statistik deskriptif, analisis faktor, uji beda $t$, dan uji regresi linear berganda. Analisis deskriptif digunakan untuk menghitung nilai minimum, nilai maksimum, nilai rata-rata, standar deviasi, dan frekuensi. Analisis faktor digunakan untuk mengelompokkan setiap butir pernyataan motivasi mahasiswa wirausaha. Uji beda $t$ digunakan untuk menganalisis perbedaan variabel penelitian berdasarkan jenis kelamin. Uji regresi linear berganda digunakan untuk menganalisis pengaruh karakteristik, motivasi berwirausaha, manajemen waktu, dan manajemen keuangan terhadap pertumbuhan usaha dan prestasi akademik mahasiswa wirausaha.

\section{HASIL}

\section{Karakteristik Responden}

Penelitian ini melibatkan 50 mahasiswa wirausaha, terdiri atas 32 orang laki-laki $(64,0 \%)$ dan 18 orang perempuan $(36,0 \%)$. Sebanyak 59,0 persen mahasiswa laki-laki berusia 19-21 tahun dengan rata-rata usia adalah 21,16 tahun. Selanjutnya, sebanyak 83,0 persen mahasiswa perempuan juga berusia 19-21 tahun dengan rata-rata usia adalah 20,67 tahun.

Responden berasal dari suku Sunda (34,0\%), Jawa (26,0\%). Betawi (10,0\%), Minang (8,0\%), melayu $(6,0 \%)$, batak $(4,0 \%)$, dan lainnya $(12,0 \%)$. Responden menjadi mahasiswa dari beragam jalur masuk perguruan tinggi. Hasil penelitian menunjukkan bahwa mahasiswa responden masuk melalui jalur SNMPTN 
(42,0\%), SBMPTN (32,0\%), UTM (16,0\%), dan BUD (10,0\%). Hasil penelitian menunjukkan bahwa proporsi paling besar mahasiswa yang menjalankan usaha berada di tingkat akhir yaitu semester VIII (56,0\%) dan X (8,0\%). Meskipun demikian, mahasiswa semester II $(6,0 \%)$, IV $(12,0 \%)$, dan VI (18,0\%) juga ada yang menjalankan usaha. Mahasiswa memperoleh uang saku dari orang tua dan beasiswa. Ratarata uang saku mahasiswa adalah sebesar Rp1.080.000,00 per bulan.

Sebagian besar mahasiswa (86,0\%) aktif dalam mengikuti kegiatan organisasi, baik di dalam maupun di luar kampus. Responden yang mengambil mata kuliah kewirausahaan atau manajemen sebanyak 62,0 persen. Namun, responden yang pernah mengikuti pelatihan kewirausahaan hanya 34,0 persen dan mengikuti Program Kreatifitas Mahasiswa bidang Kewirausahaan (PKM-K) hanya 14,0 persen.

\section{Karakteristik Keluarga}

Hasil penelitian menunjukkan bahwa rata-rata lama pendidikan ayah responden 13,96 tahun dan pendidikan ibu 12,92 tahun. Rata-rata jumlah anggota keluarga yang menjadi tanggungan adalah 4 orang. Pekerjaan ayah responden yang paling banyak adalah bekerja sebagai wiraswasta $(26,0 \%)$ sedangkan sebagian besar ibu responden $(56,0 \%)$ bekerja sebagai ibu rumah tangga. Rata-rata pendapatan keluarga responden sebesar Rp8.800.000,00 per bulan.

\section{Karakteristik Usaha}

Berdasarkan jenis usahanya, lebih dari separuh responden $(54,0 \%)$ berperan sebagai produsen, sisanya yaitu sebesar 18,0 persen sebagai distributor, dan 28,0 persen sebagai penyedia jasa. Barang hasil produksi mulai dari olahan makanan, pakaian, aksesoris, sampai properti. Sementara itu, jenis usaha jasa yang dilakukan oleh responden, seperti travel, laundry, event organizer, dan desain. Bagi jenis usaha distributor yang dilakukan oleh responden, antara lain pakaian, make-up, dan jilbab. Hanya 28,0 persen yang berwirausaha di bidang pertanian, baik pertanian dalam arti sempit (seperti bertani sayur) maupun dalam arti luas (seperti makanan yang diolah dari hasil bertani). Rata-rata responden telah berwirausaha selama 20,76 bulan dengan ratarata modal awal sebesar Rp3.890.000,00. Omset di bulan pertama usaha responden berkisar antara Rp600.000,00 per bulan sampai dengan Rp200.000.000,00 per bulan dengan rata-rata sebesar Rp16.100.000,00 per bulan. Rata-rata laba usaha yang diterima repsonden adalah $\mathrm{Rp} 4.090 .000,00$ per bulan.

\section{Motivasi Berwirausaha}

Hasil analisis faktor mengenai motivasi berwirausaha responden disajikan pada Tabel 1. Hasil penelitian menunjukkan bahwa motivasi berwirausaha yang paling sesuai dengan responden adalah "ingin menjadi seseorang yang mandiri dalam mencukupi kebutuhan". Hasil uji analisis faktor, Kaiser-Meyer-Olkin Measure of Sampling Adequacy menunjukkan angka 0,564 dan Bartlett's of Sphericity signifikan sebesar 0,000 . Analisis faktor menunjukkan empat faktor yang dapat menjelaskan sebesar 69,1 persen dari keseluruhan varian.

Faktor pertama menunjukkan capaian bisnis yang besar yang terdiri atas motif ingin membuktikan bahwa responden bisa melakukannya (berwirausaha); ingin membuka lapangan pekerjaan bagi orang lain; dan ingin membangun perusahaan sendiri. $\mathrm{Hal}$ ini menunjukkan bahwa responden percaya untuk dapat memiliki capaian lebih ketika menjadi seorang wirausahawan dibandingkan dengan harus bekerja pada orang lain. Faktor ini menjelaskan sebesar 20,0 persen dari varian. Responden percaya sebuah negara yang sektor perekonomiannya tidak stabil dan masih berkembang maka untuk dapat membentuk pertumbuhan ekonomi negara dapat dilakukan dengan membangun perusahaan dan membuka lapangan pekerjaan bagi orang lain.

Faktor kedua menunjukkan faktor intrinsik yang terdiri atas motif ingin menjadi bos pemilik usaha; ingin memiliki kepuasan diri; dan ingin bersenang-senang. Faktor ini menjelaskan 16,9 persen dari keseluruhan varian. Faktor ini menjelaskan bahwa motivasi internal responden adalah ingin menjadi bos di dalam perusahaan sendiri agar tidak terikat dengan peraturan orang lain sehingga memiliki kepuasan diri dan senang dalam menjalankan usahanya.

Faktor ketiga menunjukkan faktor keamanan yang terdiri atas motif memiliki pekerjaan yang aman dan ingin menjadi seseorang yang mandiri dalam mencukupi kebutuhan pribadi. Faktor ini menjelaskan 12,7 persen dari keseluruhan varian. Faktor ini menjelaskan bahwa dengan berwirausaha responden merasa aman dan dapat mencukupi kebutuhan sehari-harinya dengan mandiri tanpa harus bergantung pada orang lain. 
Tabel 1 Komponen analisis faktor (varimax rotation) dan communalities dari variabel motivasi

\begin{tabular}{|c|c|c|c|c|c|}
\hline Motivasi & Faktor 1 & Faktor 2 & Faktor 3 & Faktor 4 & Communality \\
\hline Ingin menjadi bos pemilik usaha & & 0,640 & & & 0,533 \\
\hline $\begin{array}{l}\text { Ingin membuktikan bahwa saya bisa } \\
\text { melakukannya }\end{array}$ & 0,585 & & & & 0,654 \\
\hline $\begin{array}{l}\text { Ingin menambah atau meningkatkan } \\
\text { pendapatan }\end{array}$ & & & & 0,905 & 0,819 \\
\hline $\begin{array}{l}\text { Ingin membuka lapangan pekerjaan } \\
\text { bagi orang lain }\end{array}$ & 0,815 & & & & 0,731 \\
\hline Ingin memiliki kepuasan diri & & 0,771 & & & 0,689 \\
\hline Memiliki pekerjaan yang aman & & & 0,736 & & 0,677 \\
\hline Ingin membangun perusahaan sendiri & 0,861 & & & & 0,814 \\
\hline Ingin memiliki kebebasan pribadi & & & & 0,457 & 0,505 \\
\hline $\begin{array}{l}\text { Ingin menjadi seseorang yang mandiri } \\
\text { dalam mencukupi kebutuhan pribadi }\end{array}$ & & & 0,880 & & 0,814 \\
\hline Ingin bersenang-senang & & 0,769 & & & 0,674 \\
\hline Variance & 2,803 & 1,699 & 1,273 & 1,135 & \\
\hline Percentage of variance & 28,034 & 16,990 & 12,725 & 11,346 & \\
\hline
\end{tabular}

Faktor keempat, yaitu faktor kebebasan pendapatan yang terdiri atas motif ingin menambah atau meningkatkan pendapatan, dan ingin memiliki kebebasan pribadi. Faktor ini menjelaskan 11,4 pesen dari keseluruhan varian. Faktor ini menjelaskan bahwa dengan berwirausaha responden memiliki kebebasan keuangan. Dengan begitu responden merasa bebas dalam mencari penghasilan dan bebas menggunakan uang yang didapatnya.

Secara keseluruhan, motif atau alasan mahasiswa mendirikan usaha telah terangkum dalam penyataan pada Tabel 1. Namun, masih ada beberapa motif atau alasan lain mahasiswa mendirikan usaha. Hasil wawancara secara mendalam, menemukan motif lain mahasiswa untuk berwirausaha yaitu tuntutan orang tua untuk menghidupi diri dan keluarga, berada di dalam keluarga yang seluruhnya memiliki profesi sebagai wirausahawan, mengikuti saran teman, dan juga ditemukan karena hobi sejak kecil.

Seseorang yang turun langsung menjalankan usaha tentu memiliki motivasi yang tinggi dalam berwirausaha. Hal ini dibuktikan oleh hasil penelitian ini yang menemukan lebih dari setengah (52,0\%) motivasi berwirausaha responden berada pada kategori tinggi $(>75,0)$. Namun, masih ada empat persen responden yang memiliki motivasi berwirausaha yang rendah $(<50,0)$. Hal ini dikarenakan responden berwirausaha dengan tuntutan untuk menghidupi diri dan keluarganya sehingga responden hanya fokus berwirausaha untuk memenuhi tuntutannya. Walaupun motif yang paling sesuai dengan responden adalah ingin menjadi seseorang yang mandiri dalam mencukupi kebutuhan yang merupakan faktor ke-3 yang ditemukan dalam penelitian ini. Berdasarkan nilai rata-rata pada hasil analisis faktor, motivasi responden dalam berwirausaha yang paling tinggi $(86,75)$ adalah motif ingin menjadi bos pemilik usaha.

\section{Manajemen Waktu}

Hasil penelitian yang disajikan pada Tabel 2 juga menunjukkan bahwa lebih sekitar 6 dari 10 $(62,0 \%)$ responden memiliki indeks manajemen waktu yang sedang. Meskipun demikian, hasil penelitian menemukan bahwa 3 dari 10 responden telah memiliki manajemen waktu yang tinggi dan kurang dari 10,0 persen responden yang memiliki manajemen waktu rendah.

Hasil penelitian juga menunjukkan rata-rata indeks manajemen waktu adalah 68,06 . Indeks minimum dan maksimum manajemen waktu adalah 25,00 dan 89,06. Dapat disimpulkan bahwa manajemen waktu yang dilakukan sebagian responden belum baik.

Tabel 2 Sebaran responden berdasarkan manajemen keuangan dan manajemen waktu

\begin{tabular}{lrr}
\hline \multicolumn{1}{c}{ Kategori } & $\mathrm{n}$ & \multicolumn{1}{c}{$\%$} \\
\hline Manajemen Waktu & & \\
Rendah $(<50)$, & 4 & 8,0 \\
Sedang $(50-75)$ & 31 & 62,0 \\
Tinggi $(>75)$ & 15 & 30,0 \\
\hline Total & 50 & 100,0 \\
\hline Manajemen Keuangan & & \\
\hline Rendah $(<50)$ & 5 & 10,0 \\
Sedang $(50-75)$ & 33 & 66,0 \\
Tinggi $(>75)$ & 12 & 24,0 \\
\hline Total & 50 & 100,0 \\
\hline
\end{tabular}




\section{Manajemen Keuangan}

Investasi merupakan hal yang paling bermanfaat untuk masa depan. Rendahnya investasi yang dilakukan oleh responden dikarenakan hasil penjualan masih dalam skala kecil. Responden masih buruk dalam hal pembayaran pajak. Hal ini karena hanya 16,0 persen responden yang telah mengurus izin usaha dan diwajibkan pajak. Berdasarkan hasil wawancara mendalam, alasan tidak mengurus perijinan usaha karena usaha yang dijalani mahasiswa tidak memiliki rumah produksi atau tempat yang dikhususkan untuk usaha. Hasil penelitian menunjukkan bahwa proporsi terbesar responden masuk dalam kategori sedang dalam hal manajemen keuangannya. Hasil penelitian menemukan hampir satu dari empat responden yang telah memiliki manajemen keuangan tinggi. Sementara itu, proporsi paling sedikit adalah mahasiswa yang masuk dalam kategori manajemen keuangan rendah (Tabel 2). Rata-rat indeks manajemen keuangan responden adalah 68,09. Sementara itu, nilai minimum dan maksimum indeks manajemen waktu adalah 28,13 dan 96,88.

\section{Pertumbuhan Usaha}

Pertumbuhan usaha merupakan salah satu indikator dari perkembangan usaha. Dalam penelitian ini, pertumbuhan usaha dilihat dari pertumbuhan penjualan. Hasil penelitian menunjukkan bahwa pertumbuhan penjualan berkisar antara $-10,39$ sampai dengan 124,16 dengan nilai rata-rata sebesar 21,29. Nilai minimum dari pertumbuhan penjualan adalah 10,39 yang menunjukkan bahwa usaha yang dilakukan mengalami penurunan penjualan sebesar 10,39 persen. Hasil penelitian menemukan bahwa proporsi responden dengan pertumbuhan penjualan kurang dari 0,0 persen per bulan hanya sebanyak 6,0 persen. Sementara itu, proporsi terbesar adalah responden dengan pertumbuhan usaha dalam interval $0,0-20,0$ persen per bulan $(78,0 \%)$. Penelitian ini menemukan bahwa telah ada 18,0 persen responden yang pertumbuhan penjualannya telah lebih dari 20,0 persen per bulan.

\section{Prestasi Akademik}

Hasil penelitian, seperti yang tersaji pada Tabel 3 , menunjukkan bahwa persentase tertinggi IPK responden laki-laki $(43,8 \%)$ terletak pada kategori 2,50-3,00 dengan nilai rata-rata IPK sebesar 2,88. Adapun IPK terendah dan tertinggi responden laki-laki adalah 1,80 dan 3,87 .
Tabel 3 Sebaran responden berdasarkan prestasi akademik

\begin{tabular}{lrrrrrr}
\hline \multirow{2}{*}{ IPK } & \multicolumn{2}{c}{$\mathrm{L}$} & \multicolumn{2}{c}{$\mathrm{P}$} & \multicolumn{2}{c}{ Total } \\
\cline { 2 - 7 } & $\mathrm{n}$ & $\%$ & $\mathrm{n}$ & $\%$ & $\mathrm{n}$ & $\%$ \\
\hline$<2,50$ & 5 & 15,6 & 0 & 0,0 & 5 & 10,0 \\
$2,50-3,00$ & 14 & 43,8 & 3 & 16,7 & 17 & 34,0 \\
$3,01-3,50$ & 12 & 37,5 & 8 & 44,4 & 20 & 40,0 \\
$>3,50$ & 1 & 3,1 & 7 & 38,9 & 8 & 16,0 \\
\hline Total & 32 & 100,0 & 18 & 100,0 & 50 & 100,0 \\
\hline Keterangan: L: Laki-laki; P: Perempuan & \multicolumn{1}{c}{}
\end{tabular}

Sementara itu, persentase tertinggi IPK responden perempuan $(40,0 \%)$ terletak pada kategori 3,01-3,50 dengan nilai rata-rata IPK sebesar 3,29. Adapun IPK terendah dan tertinggi responden perempuan adalah 2,50 dan 3,80. Hasil uji beda t menemukan bahwa IPK antara responden laki-laki dan perempuan berbeda signifikan $(p=0,000)$. Hal ini menunjukkan bahwa prestasi akademik responden perempuan lebih tinggi dibandingkan dengan prestasi akademik responden laki-laki.

\section{Pengaruh Karakteristik (Responden, Keluarga, dan Usaha), Motivasi Berwirausaha, Manajemen Waktu, dan Manajemen Keuangan terhadap Pertumbuhan Usaha}

Model yang digunakan untuk menganalisis pengaruh karakteristik responden, karakteristik keluarga, karakteristik usaha, motivasi berwirausaha, manajemen waktu, dan manajemen keuangan terhadap pertumbuhan usaha memiliki koefisien determinasi (adjusted $R^{2}$ ) sebesar 0,204 . Nilai ini menunjukkan bahwa sebesar 20,4 persen pertumbuhan usaha dipengaruhi oleh variabel dalam penelitian, sisanya sebesar 79,6 persen dipengaruhi oleh variabel lain yang tidak diteliti (Tabel 4).

Hasil penelitian menunjukkan bahwa pekerjaan ayah $(p=0,019 ; \beta=0,343)$ berpengaruh positif dan signifikan terhadap pertumbuhan usaha. Hal ini berarti responden yang memiliki ayah wirausaha memiliki pertumbuhan usaha 0,343 poin lebih tinggi dibandingkan dengan responden yang memiliki ayah yang bekerja di bidang nonwirausaha. Hasil menunjukkan bahwa pendapatan keluarga $(p=0,013$; $\beta=0,447$ ) juga berpengaruh positif dan signifikan terhadap pertumbuhan usaha. Hal ini berarti setiap kenaikan 1 satuan pendapatan keluarga akan meningkatkan pertumbuhan usaha yang dimiliki responden sebesar 0,477 poin. Adapun karakteristik responden, karakteristik usaha, motivasi berwirausaha, manajemen waktu, dan manajemen keuangan tidak berpengaruh signifikan terhadap pertumbuhan usaha (Tabel 4). 
Tabel 4 Koefisien uji regresi karakteristik responden, karakteristik keluarga, karakteristik usaha, motivasi berwirausaha, manajemen waktu, dan manajemen keuangan terhadap pertumbuhan usaha

\begin{tabular}{|c|c|c|c|}
\hline Variabel & B & $\beta$ & Sig. \\
\hline Konstanta & 1496,338 & & 0,248 \\
\hline Usia (tahun) & $-52,410$ & $-0,188$ & 0,302 \\
\hline $\begin{array}{l}\text { Jenis kelamin } \\
\text { ( } 0=\text { perempuan, } \\
1=\text { laki-laki) }\end{array}$ & $-162,442$ & $-0,205$ & 0,293 \\
\hline $\begin{array}{l}\text { Keikutsertaan } \\
\text { organisasi }(0=\text { tidak, } \\
1=y a)\end{array}$ & 264,033 & 0,241 & 0,215 \\
\hline $\begin{array}{l}\text { Keikutsertaan } \\
\text { pelatihan }(0=\text { tidak, } \\
1=y a)\end{array}$ & 178,381 & 0,222 & 0,226 \\
\hline $\begin{array}{l}\text { Keikutsertaan } \\
\text { PKMK }(0=\text { tidak, } \\
1=y a)\end{array}$ & $-72,491$ & $-0,066$ & 0,700 \\
\hline $\begin{array}{l}\text { Keikutsertaan MK } \\
(0=\text { tidak, } 1=y a)\end{array}$ & $-142,401$ & $-0,182$ & 0,290 \\
\hline $\begin{array}{l}\text { Pendidikan ayah } \\
\text { (tahun) }\end{array}$ & $-26,756$ & $-0,268$ & 0,157 \\
\hline $\begin{array}{l}\text { Pekerjaan ayah } \\
(0=\text { non-wirausaha, } \\
1=\text { wirausaha) }\end{array}$ & 297,391 & 0,343 & $0,019^{*}$ \\
\hline $\begin{array}{l}\text { Pendapatan } \\
\text { Keluarga } \\
\text { (Rp000/bulan) }\end{array}$ & 0,021 & 0,447 & $0,013^{*}$ \\
\hline $\begin{array}{l}\text { Bidang usaha } \\
(0=\text { non-pertanian, } \\
1=\text { pertanian })\end{array}$ & $-160,378$ & $-0,189$ & 0,227 \\
\hline Lama usaha (bulan) & 4,407 & 0,221 & 0,175 \\
\hline $\begin{array}{l}\text { Modal awal usaha } \\
\text { (Rp000) }\end{array}$ & 0,001 & 0,150 & 0,386 \\
\hline Faktor 1 (indeks) & $-2,663$ & $-0,133$ & 0,526 \\
\hline Faktor 2 (indeks) & $-0,847$ & $-0,055$ & 0,805 \\
\hline Faktor 3 (indeks) & 4,007 & 0,221 & 0,172 \\
\hline Faktor 4 (indeks) & 0,605 & 0,033 & 0,900 \\
\hline $\begin{array}{l}\text { Manajemen } \\
\text { keuangan (indeks) }\end{array}$ & $-3,045$ & $-0,110$ & 0,544 \\
\hline $\begin{array}{l}\text { Manajemen waktu } \\
\text { (indeks) }\end{array}$ & 1,907 & 0,062 & 0,714 \\
\hline $\mathrm{F}$ & & & 1,699 \\
\hline $\mathrm{R}$ & & & 0,497 \\
\hline Adjusted $R^{2}$ & & & 0,204 \\
\hline Sig. & & & 0,095 \\
\hline
\end{tabular}

\section{Pengaruh Karakteristik (Responden,} Keluarga, dan Usaha), Manajemen Waktu, Manajemen Keuangan, dan Pertumbuhan Usaha terhadap Prestasi Akademik

Pada Tabel 5, hasil analisis regresi linier berganda menunjukkan bahwa nilai adjusted $R^{2}$ pada model tersebut adalah sebesar 0,389. Nilai tersebut menunjukkan bahwa sebesar 38,9 persen prestasi akademik (IPK) responden dipengaruhi oleh variabel dalam penelitian, sisanya sebesar 61,1 persen dipengaruhi oleh variabel lain.

Penelitian ini menemukan bahwa jenis kelamin $(p=0,000 ; \beta=-0,574)$ berpengaruh negatif dan sangat signifikan terhadap prestasi akademik. Artinya, responden yang berjenis kelamin lakilaki memiliki prestasi akademik sebesar 0,574 poin di bawah prestasi akademik perempuan. Selain itu, jalur masuk mahasiswa $(p=0,042$; $\beta=0,271$ ) berpengaruh positif dan signifikan terhadap prestasi akademik. Hal ini menunjukkan bahwa responden yang masuk melalui jalur SNMPTN memiliki prestasi akademik yang lebih tinggi dibandingkan responden yang masuk melalui jalur SBMPTN, UTM, dan BUD. Hasil juga menunjukkan bahwa pertumbuhan usaha ( $p=0,019 ; \quad \beta=-0,349)$ berpengaruh negatif signifikan terhadap prestasi akademik wirausaha muda. Hal ini berarti setiap kenaikkan 1 satuan pertumbuhan usaha akan menurunkan prestasi akademik sebesar 0,349 poin.

Tabel 5 Koefisien uji regresi karakteristik responden, karakteristik keluarga, pertumbuhan usaha, manajemen keuangan, dan manajemen waktu terhadap prestasi akademik

\begin{tabular}{|c|c|c|c|}
\hline Variabel & B & $\beta$ & Sig. \\
\hline Konstanta & 4,095 & & 0,000 \\
\hline Usia (tahun) & $-0,081$ & $-0,223$ & 0,092 \\
\hline $\begin{array}{l}\text { Jenis kelamin } \\
\text { (0=perempuan, } \\
1=\text { laki-laki) }\end{array}$ & $-0,536$ & $-0,574$ & $0,000^{\star *}$ \\
\hline $\begin{array}{l}\text { Jalur masuk } \\
(0=\text { bukan SNMPTN, } \\
1=\text { SNMPTN })\end{array}$ & 0,244 & 0,271 & $0,042^{*}$ \\
\hline $\begin{array}{l}\text { Beasiswa }(0=\text { tidak } \\
\text { menerima, } \\
1=\text { menerima) }\end{array}$ & 0,168 & 0,185 & 0,210 \\
\hline $\begin{array}{l}\text { Keikutsertaan PKMK } \\
\text { (0=tidak, } 1=\mathrm{ya})\end{array}$ & $-0,386$ & $-0,285$ & $0,038^{*}$ \\
\hline $\begin{array}{l}\text { Pendidikan ibu } \\
\text { (tahun) }\end{array}$ & $-0,010$ & $-0,102$ & 0,494 \\
\hline $\begin{array}{l}\text { Pekerjaan ibu } \\
\text { (0=tidak bekerja, } \\
1=\text { bekerja) }\end{array}$ & 0,176 & 0,195 & 0,144 \\
\hline $\begin{array}{l}\text { Pendapatan } \\
\text { Keluarga } \\
\text { (Rp000/bulan) }\end{array}$ & 0,001 & 0,000 & 0,094 \\
\hline $\begin{array}{l}\text { Pertumbuhan usaha } \\
\text { (\%/bulan) }\end{array}$ & $-0,000$ & $-0,349$ & 0,019 * \\
\hline $\begin{array}{l}\text { Manajemen } \\
\text { keuangan (indeks) }\end{array}$ & 0,009 & 0,278 & $0,046^{\star}$ \\
\hline $\begin{array}{l}\text { Manajemen waktu } \\
\text { (indeks) }\end{array}$ & 0,004 & 0,111 & 0,402 \\
\hline $\mathrm{F}$ & & & 3,833 \\
\hline $\mathrm{R}$ & & & 0,725 \\
\hline Adjusted $R^{2}$ & & & 0,389 \\
\hline Sig. & & & 0,001 \\
\hline
\end{tabular}


Penelitian juga menemukan bahwa keikutsertaan responden dalam kegiatan PKMK $(p=0,038 ; \beta=-0,285)$ berpengaruh negatif signifikan terhadap prestasi akademik. Hal ini berarti responden yang mengikuti PKM-K memiliki prestasi akademik 0,285 poin lebih rendah dibandingkan dengan responden yang tidak mengikuti PKM-K. Temuan lain dalam penelitian ini adalah adanya pengaruh positif dan signifikan manajemen keuangan ( $p=0,046$; $\beta=0,278$ ) terhadap prestasi akademik. Hal ini berarti setiap kenaikan 1 satuan indeks manajemen keuangan akan meningkatkan prestasi akademik responden sebesar 0,278 poin.

\section{PEMBAHASAN}

Menurut Undang-Undang Nomor 20 Tahun 2008 tentang Usaha Mikro, Kecil, dan Menengah (UMKM), usaha yang dikelola oleh mahasiswa tergolong kedalam UMKM skala mikro. Kriteria usaha mikro adalah memiliki kekayaan bersih paling banyak Rp50.000.000,00 dan tidak termasuk tanah serta bangunan tempat usaha atau memiliki hasil penjualan tahunan paling banyak Rp300.000.000,00. Pertumbuhan usaha dapat dilihat dari pertumbuhan jumlah produksi, penjualan, pendapatan, dan laba. Penurunan penjualan yang dialami mahasiswa wirausaha dikarenakan penurunan minat dan jumlah konsumen terhadap produk tersebut. Berdasarkan hasil wawancara mendalam, pertumbuhan yang tinggi disebabkan oleh permintaan terhadap produk tersebut semakin tinggi.

Berdasarkan karakteristik usaha, sebagian besar responden $(72,0 \%)$ berwirausaha di bidang nonpertanian dan sisanya berwirausaha di bidang pertanian. Usaha di bidang pertanian yang dilakukan mahasiswa wirausaha berupa olahan makanan hasil pertanian seperti susu, singkong, dan beras ketan serta produksi sayuran atau bertani. Ginting dan Yuliawan (2015) mengatakan bahwa minat mahasiswa berwirausaha dipengaruhi oleh variabel kepribadian, ketersediaan informasi kewirausahaan, dan kepemilikan jaringan sosial.

Berdasarkan motivasi berwirausaha, motivasi yang paling sesuai dengan mahasiswa wirausaha adalah ingin menjadi seseorang yang mandiri dalam mencukupi kebutuhan. Hal ini berbeda dengan penelitian terdahulu mengenai wirausahawan di Serbia (Stefanovic, Prokic, dan Rankovic, 2010), wirausahawan di Turki (Benzing, Chu, dan Kara, 2009), dan wirausahawan di Kenya dan Ghana (Chu, Benzing, dan Mcgee, 2007) yang menyebutkan bahwa motivasi yang paling penting adalah meningkatkan pendapatan. Perbedaan tersebut disebabkan karakteristik responden yang berbeda. Pada penelitian ini, responden berusia 19-24 tahun yang berada pada masa peralihan dari remaja ke masa dewasa awal (Santrock, 2011). Masa peralihan tersebut merupakan masa peralihan dari ketergantungan ke masa mandiri, baik segi ekonomi, perkembangan karir, kebebasan menentukan diri sendiri, dan pandangan tentang masa depan yang lebih realistis.

Berdasarkan analisis faktor yang dilakukan dalam penelitian ini, ditemukan empat faktor yang dapat menjelaskan sebesar 69,06 persen dari keseluruhan varian. Keempat faktor ini hampir sama seperti penelitian yang dilakukan oleh Stefanovic, Prokic, dan Rankovic (2010) pada wirausahawan di Serbia. Keempat faktor tersebut, yaitu capaian bisnis yang besar (greater business achievement), faktor kebebasan (independent factor), faktor intrinsik (intrinsic factor), dan faktor keamanan kerja (job security factor). Namun, pada penelitian ini, faktor kebebasan dan keamanan menjadi satu faktor serta faktor lainnya adalah faktor pendapatan sesuai dengan hasil penelitian Benzing, Chu, dan Kara (2009). Hasil ini sesuai dengan Aquino dan Freeman (2009) yang menemukan bahwa imbalan keuangan (financial reward) dalam memotivasi perilaku bewirausaha adalah prinsip dasar untuk memulai berbisnis.

Hasil penelitian menunjukkan bahwa manajemen waktu yang paling sering dilakukan oleh mahasiswa wirausaha adalah tetap bersosialisasi dengan teman dan lingkungan sekitar. Selanjutnya, mendahulukan kegiatan yang paling penting dan membuat prioritas kegiatan. Kedua hal tersebut berkaitan dengan aktivitas mahasiswa wirausaha yang tidak hanya berfokus pada wirausaha saja. Namun, hal tersebut bertolak belakang dengan skor rata-rata yang paling kecil yaitu selalu tepat waktu dalam menjalankan setiap agenda kegiatan dan mendahulukan kepentingan kuliah dibandingkan dengan bekerja. Hal tersebut karena ada kegiatan yang mendesak dan prioritas kegiatan responden yang berbeda. Penelitian Ariyanto (2004) yang menemukan bahwa manajemen waktu di sektor informal lebih kecil dibandingkan bekerja pada sektor formal. Selanjutnya Kartadinata dan Tjundjing (2008) mengatakan bahwa ketidakmampuan dalam mengatur waktu dengan baik dapat meningkatkan prokrastinasi akademik 
(penundaan menyelesaikan tugas-tugas akademik) pada mahasiswa apabila dilakukan secara sengaja.

Selain itu, penelitian ini juga menemukan bahwa manajemen keuangan mahasiswa wirausaha berada pada kategori sedang yang artinya mahasiswa sudah mampu mengelola keuangan, baik dalam hal memisahkan uang usaha dengan uang pribadi, menghitung keuntungan bersih, membandingkan pendapatan dan pengeluaran, maupun menyisihkan uang untuk bersedekah. Namun, mahasiswa masih kurang dalam perencanaan keuangan dengan disiplin, melakukan investasi terhadap pengembangan usaha serta membayar pajak. Menurut Goldsmith (2010), manajemen keuangan terdiri atas perencanaan (planning), aksi (action), dan pascaperencanaan (post-planning). Oleh karena itu, mahasiswa wirausaha sudah baik dalam aksi dan evaluasi, tetapi masih kurang baik dalam hal perencanaan. Hasil penelitian Heckman, Lim, dan Montalto (2014) menemukan bahwa semakin baik pengetahuan tentang keuangan yang dimiliki mahasiswa maka kemampuan dalam mengatasi tekanan finansial akan semakin baik.

Dalam menjalankan usaha dengan menargetkan pertumbuhan usaha perlu memerlukan waktu yang lebih lama untuk mengelola usaha. Hal tersebut merupakan trade off bagi mahasiswa wirausaha dimana mahasiswa memilih mencurahkan waktunya untuk berwirausaha dengan mengorbankan waktunya untuk perkuliahan.

Hasil penelitian juga menemukan bahwa mahasiswa wirausaha yang memiliki ayah yang bekerja di bidang wirausaha memiliki pertumbuhan usaha lebih tinggi daripada mahasiswa wirausaha yang memiliki ayah yang bekerja di bidang nonwirausaha. Berdasarkan hasil wawancara secara mendalam, hal ini dikarenakan seorang ayah yang berwirausaha lebih mendukung anaknya dalam berwirausaha. Selain dapat memotivasi anaknya untuk berwirausaha, seorang ayah yang berwirausaha juga bisa lebih banyak memberikan pelajaran tentang mengelola usaha dibandingkan ayah yang tidak memiliki pengalaman dalam bewirausaha. Selain itu, ayah yang memiliki pendapatan tinggi dapat memberikan dukungan berupa modal usaha dibandingkan ayah yang berpenghasilan rendah.

Penelitian ini ingin mengeksplorasi variabel yang memengaruhi prestasi belajar pada mahasiswa wirausaha. Variabel yang dapat memengaruhi prestasi akademik adalah komunikasi, fasilitas belajar, dan bimbingan yang tepat (Mushtaq \& Khan, 2012) dan strategi pengaturan diri dalam belajar (Novita \& Latifah, 2014). Strategi pengaturan diri dalam belajar dilakukan agar tujuan pembelajaran dapat dicapai. Rachmah (2015) mengatakan bahwa strategi pengaturan diri dalam belajar yang dilakukan dipengaruhi oleh situasi dan karakteristik setiap individu, serta tidak terlepas dari dukungan sosial yang diberikan kepada mereka. Hasil uji beda menemukan bahwa IPK mahasiswa wirausaha perempuan lebih baik dibandingkan dengan mahasiswa wirausaha laki-laki. Hal ini sejalan dengan penelitian Novita dan Latifah (2014) dan Redzuan et al. (2010) yang memperlihatkan adanya perbedaan yang signifikan antara anak perempuan dan laki-laki dalam pencapaian prestasi akademik, yaitu perempuan memiliki prestasi akademik yang lebih tinggi dibandingkan laki-laki. Hal tersebut dikarenakan anak perempuan cenderung memiliki persepsi yang tinggi terhadap pengaturan diri dalam aktivitas akademik dibandingkan dengan lakilaki (Caprara et al., 2008). Griffin et al. (2012) perbedaan gender dalam prestasi akademik dimediatori oleh keterampilan dan kemampuan menggunakan strategi di dalam belajar.

Sementara itu, dalam penelitian ini menemukan bahwa prestasi akademik mahasiswa wirausaha dipengaruhi secara negatif signifikan oleh keikutsertaan mahasiswa dalam kegiatan PKM-K dan pertumbuhan usaha yang menurun. Temuan ini mengindikasikan bahwa keikutsertaan mahasiswa wirausaha dalam PKM-K membutuhkan pengelolaan waktu yang baik dan penetapan skala prioritas. Oleh karenanya, ketika keikutsertaan mahasiswa wirausaha dalam PKM-K membuat mahasiswa tidak melakukan manajemen waktu yang baik dan tidak dapat membuat skala prioritas untuk akademik maka dapat menurunkan prestasi akademiknya. Begitu pula ketika pertumbuhan usaha menurun. Pertumbuhan usaha yang menurun memungkinkan membuat mahasiswa wirausaha menjadi mempunyai waktu yang lebih banyak karena usaha yang dijalankan sedang tidak menyita waktunya. Hal ini tentu saja membuat mahasiswa wirausaha mempunyai kesempatan untuk meningkatkan perestasi akademiknya. Selain itu, penelitian ini menemukan bahwa manajemen waktu tidak berpengaruh secara langsung terhadap prestasi akademik. Hasil penelitian ini sejalan dengan penelitian sebelumnya oleh Puspitawati (2004) yang menemukan bahwa kemampuan mahasiswa dalam mengefisiensikan 
manajemen waktu, pekerjaan, keuangan, dan stres tidak berpengaruh secara langsung terhadap pencapaian prestasi akademiknya. Namun, bertolak belakang dengan penelitian sebelumnya oleh Pehlivan (2013) yang menemukan bahwa keterampilan manajemen waktu yang baik akan meningkatkan prestasi akademik seseorang.

\section{SIMPULAN DAN SARAN}

Peran mahasiswa dalam berwirausaha lebih banyak berperan sebagai produsen dan bidang usaha yang paling banyak dilakukan oleh mahasiswa adalah bidang nonpertanian. Motivasi berwirausaha pada mahasiswa wirausaha pada penelitian ini berada pada kategori tinggi. Faktor motivasi bagi mahasiswa wirausaha yang ditemukan dalam penelitian ini ada empat, yaitu capaian bisnis yang besar, faktor intrinsik, faktor kebebasan dan keamanan, serta faktor pendapatan. Faktor yang paling memotivasi mahasiswa dalam berwirausaha adalah faktor capaian bisnis yang besar. Manajemen waktu dan manajemen keuangan mahasiswa wirausaha ditemukan proporsi terbesar berada pada kategori sedang. Selanjutnya, penelitian ini menemukan bahwa peningkatan pertumbuhan usaha mahasiswa wirausaha dipengaruhi secara positif oleh ayah yang wirausaha dan peningkatan pendapatan keluarga. Sementara peningkatan prestasi akademik mahasiswa wirausaha dipengaruhi oleh ketidakikutsertaan mahasiswa dalam kegiatan PKM-K, penurunan pertumbuhan usaha, dan peningkatan manajemen keuangan.

Berdasarkan hasil penelitian, disarankan bagi mahasiswa memiliki koping strategi sehingga ada keseimbangan antara prestasi akademik dengan pertumbuhan usaha. Mahasiswa yang memilih untuk berwirausaha sebaiknya meningkatkan keterampilan manajemen keuangan dan waktunya agar dapat menyeimbangkan kepentingan usaha dan kegiatan akademiknya. Saran bagi institusi perguruan tinggi adalah institusi diharapkan dapat mendukung mahasiswa yang berwirausaha dengan memberikan program khusus bagi mahasiswa wirausaha yang menekankan pada keseimbangan antara usaha dan akademik. Variabel yang diteliti dan diamati dalam penelitian ini hanya terbatas pada variabel motivasi berwirausaha, manajemen waktu, dan manajemen keuangan sehingga saran untuk penelitian selanjutnya adalah bisa meneliti variabel lain, seperti tujuan (goal) atau orientasi usaha, hambatan, dan strategi untuk mengatasi hambatan tersebut.

\section{DAFTAR PUSTAKA}

Amalia, R. 2011. Analisis faktor-faktor yang mempengaruhi pekerja untuk berwirausaha di Kota Pekanbaru (analisis pendekatan etnis) (Tesis). Sekolah Pascasarjana, Universitas Andalas. Padang, Indonesia. Diambil dari: http://pasca.unand.ac.id/id/wpcontent/uploads/2011/09/artikel-tesisreni-amalia.pdf.

Ariyanto, A. (2004). Manajemen waktu dan ekonomi rumah tangga pekerja pada sektor industri formal berdasarkan gender (Tesis). Institut Pertanian Bogor, Bogor, Indonesia.

Aquino, K., Freeman, D. (2009). Moral identity in business situations: a social-cognitive framework for understanding moral functioning. Narvaez, D., Lapsley, D. K., editor. Personality, identity, and character. New York, NY: Cambrigde University Press.

Benzing, C., Chu, H. M., Kara, O. (2009). Entrepreneurs in Turkey: a factor analysis of motivation, success factors, and problems. Journal of Small Business Management, 47(1), 58-91.

[BPS]. Badan Pusat Statistika. (2015a).Keadaan pekerja di Indonesia Agustus 2015. Diambil dari http://www.bps.go.id/website/pdfpublikasi/ Keadaan-Pekerja-di-Indonesia-Agustus2015.pdf.

Badan Pusat Statistika. (2015b). Laporan bulanan data sosial ekonomi. Diambil dari http://www.bps.go.id/website/pdf_publikas i/Laporan-Bulanan-Data-Sosial-EkonomiNovember-2015.pdf.

Caprara, G. V., Fida, R., Vecchione, M., Del Bove, G., Vecchio, G. M., Barbaranelli, C., Bandura, A. (2008). Longitudinal analysis of the role of perceived selfefficacy for slf-regulated learning in academic and achievement. Journal of Education Psychology, 100(3), 525-534.

Chu, H. M., Benzing, C., Mcgee, C. (2007). Ghanaian and Kenyan entrepreneurs: a comparative analysis of their motivation, success characteristic and problem. Journal of Developmental Entepreneurship, 12(3), 295-322.

Claessens, B., Van Eerde, W., Rutte, C., Rue, R. (2007). A review of time management 
literature. Personal Review, 36(2), 255 276.

Ginting, M \& Yuliawan, E. (2015). Analisis faktor-faktor yang mempengaruhi minat berwirausaha mahasiswa (studi kasus pada STMIK Mikroskil Medan). Jurnal Wira Ekonomi Mikrosil, 5(01), 61-69.

Goldsmith, E. B. (2010). Resource management for individuals and families. New Jersey, GD: Person Education, Inc.

Griffin, R., MacKewn, A., Moser, E., Van Vuren, K. W. (2012). Do learning and study skills affect academic performance? An empirical Investigation. Contemporary Issues in Education Reserch, 5(2), 109116.

Heckman, S., Lim H., \& Montalto, C. (2014). Factors related to financial stress among collage students. Journal of Financial Therapy, 5(1), 19-39.

Kartadinata, I., Tjundjing, S. (2008). I love you tomorrow: Prokrastinasi akademik dan manajemen waktu. Indonesian Psychological Journal, 23(2), 109-119.

Muhdar, H. M. (2015). Potret ketenagakerjaan, pengangguran, dan kemiskinan Indonesia: Masalah dan solusi. Jurnal AlBuhuts, 11(1), 42-66.

Mushtaq, I., Khan, S. N. (2012). Factors affecting students' academic performance. Global Journal of Management and Business Research, 12(9), 17-22.

Novita, L., Latifah, M. (2014). Strategi pengaturan diri dalam belajar sebagai mediator harapan orangtua dan motivasi instrinsik terhadap prestasi akademik. Jurnal IImu Keluarga \& Konsumen, 7(3), 143-153.

Pambudy, R., Burhanuddin., Priatna, W. B., Rosiana, N. (2011). Analisis perilaku wirausaha mahasiswa Institut Pertanian Bogor. In Nurmalina, R., Priatna, W. B., Jahroh, S., Nurhayati, P., editor. Prosiding Seminar Penelitian Unggulan Departemen Agrinisnis; 2011; 7,14 Des; Bogor, Indonesia, hlm 179-196. Bogor, ID: Departemen Agribisnis.

Pehlivan, A. (2013). The effect of the time management skills of student taking financial course on their course grades and grade point averages. International Journal of Business and Social Scince, 4(5), 196-203.

Perren, L. (1999). Factors in the growth of micro-entreprises: developing a framework. Journal of Small Business and Enterprise Development, 6(4), 366385.

Puspitawati, H. (2004). Pengaruh efisiensi manajemen waktu, pekerjaan, keuangan dan stres serta pola konsumsi pangan terhadap pencapaian prestasi akademik pada mahasiswa Departemen GMSK FAPERTA - IPB [Abstrak]. Respository Institut Pertanian Bogor. Diambil dari http://repository.ipb.ac.id/handle/1234567 89/6620.

Rachmah, D. H. (2015). Regulasi diri dalam belajar pada mahasiswa yang memiliki peran banyak. Jurnal Psikologi, 42(1), 6177.

Riyanti, B. (2003). Kewirausahaan dari sudut pandang psikologi kepribadian. Jakarta, ID: Gramedia.

Santrock, J. W. (2011). Perkembangan masa hidup. Sallama, N. I., editor. Life span development $13^{\text {th }}$ edition. Jakarta, ID: Erlangga.

Stefanovic, I., Prokic, S., Rankovic, L. (2010). Motivational and succes factors of entrepreneur: The evidence a developing country. Zb. Rad. Ekon. Fak. Rij, 28(2), 251-269.

Sukidjo. (2005). Peran kewirausahaan dalam mengatasi pengangguran di Indonesia. Jurnal Economia, 1(1), 17-28.

Toledo, L. A., Diaz, P. R., Jimenez, C. J. C., Sanchez, M. P. S. (2012). Defining success in subsistence businesses. Journal of Bussiness Reserch, 65, 16581664.

Redzuan, M., Juhari, R. B.,Yousefi, F., Mansor,B. M., Talib, M., A. (2010). The relationship between gender, age, depression and academic achievement. Current Research in Psychology, 1(1), 61-66. 